\title{
Enhancement of the capacitance properties and the photoelectrochemical performances of P3HT film by incorporation of nickel oxide nanoparticles
}

\author{
Yasser Ghalmi $^{1 *}$, Farid Habelhames ${ }^{1 *}$, Abdelfetteh Sayah ${ }^{1 *}$, Ahmed Bahloul ${ }^{1}$, Balkacem \\ Nessark $^{1}$, Hassina Derbal-Habak ${ }^{2}$, Yvan Bonnassieux ${ }^{3}$, Jean Michel Nunzi ${ }^{4}$
}
${ }^{1}$ Laboratoire d'Electrochimie et Matériaux (LEM), Faculté de Technologie. Département de Génie des Procédés Université Ferhat Abbas Sétif 1, 19000 - Algérie
${ }^{2}$ Laboratoire des Technologies Innovantes (LTI), Université de Jules Verne, IUT de l'Oise Allée de la Faïencerie 60100 Creil, France
${ }^{3}$ Laboratoire de Physique des Interfaces et des Couches Minces, Ecole Polytechnique, CNRS UMR 7647, 91128 Palaiseau, France
${ }^{4}$ Department of Chemistry Queen's University Kingston, ON K7L 3N6, Canada

\begin{abstract}
:
In this work, the P3HT modified films by incorporation of different amounts of nickel oxide $(\mathrm{NiO})$ were dissolved and deposited by spin-coating method on the indium tin-oxide (ITO) substrates. The nickel oxide powder was synthesized by chronoamperometry method. The effects of $\mathrm{NiO}$ content on the morphology structure and optical properties of P3HT films were investigated by means of XRD, SEM, AFM and UV-vis spectroscopy, the electrochemical and photoelectrochemical performance were evaluated by cyclic voltammetry $(\mathrm{CV})$, electrochemical impedance spectroscopy (EIS), galvanostatic charge-discharge tests and photocurrent measurements.
\end{abstract}

The results showed that the $\mathrm{NiO}$ dispersed uniformly in P3HT thin films and modified the surface roughness and absorption of thin films after deposition. We observed a remarkable improvement of photocurrent density and electrochemical capacitance of these modified surface electrodes for an amount of $\mathrm{NiO}$ ranging between 1 and $10 \mathrm{wt} \%$. The obtained specific capacitance for the P3HT material alone is about $20.8 \mathrm{Fg}^{-1}$, this value was increased up to 81.4 $\mathrm{Fg}^{-1}$ for the composite film P3HT-NiO $10 \mathrm{wt} \%$ at $0.1 \mathrm{~A} / \mathrm{g}$.

Keywords: NiO, P3HT, composite film, photocurrent, supercapacitors. 


\section{Introduction}

In recent years, increased demand for renewable energy resources take a major attention due to the limited availability of fossil fuels. In order to tackle the problem, researches focused on organic photovoltaic (OPV) devices seem to be one of the issues that may be a solution substitute to the classical energy suppliers. In addition to their powerful conversion rate, organic photovoltaic (OPV) devices are easy to manufacture, low-cost, light weight and eco-friendly compared to classic energy supplier's appliances. In the other hand, organic photovoltaic (OPV) devices are proved to be of high capability for large area roll-to-roll manufacturing [1-3] and energy storage systems such electrochemical batteries and their capacitors (ECs) [4-8]. Subsequently, organic photovoltaic (OPV) devices are playing a major role in both essential commodities and electronic systems.

The best known basic component of organic photovoltaic (OPV) devices is the Poly (3hexylthiophene) (P3HT) still submitted to researches in terms of electrochemical configuration modification by addition or incorporation of other chemicals. So, several researchers worldwide have studied P3HT as an electron donor (p-type semiconductor) in (OPVs) to improve energy conversion efficiency [9-11] and recently, in supercapacitors due to their promising capacitive properties. The most advantageous aspect of P3HT is the easiness to dissolve in a wide range of organic solvents, fact that enables its deposition over a large area following different deposition techniques such as spray deposition, spin coating and dip coating $[12,13]$.

The nickel oxide $(\mathrm{NiO})$ is a p-type semiconductor which has a band energy gap at 3.5-4.0 eV range [14]. The remarkable aspect of the nickel oxide (NiO) that attracted searchers' attention [15] is its polyvalent use in many applications i.e. transparent conducting films, anode buffer layer in (OPVs) [16] and electrochemical super-capacitors [16-22]. To produce NiO 
films, there are several available technical ways; those deserving mention are sol-gel [14], chemical deposition [23], spray pyrolysis [24], thermal evaporation [25], sputtering [26] and electro deposition [27].

Among the conducting polymers, poly (3-hexylthiophene) (P3HT), polythiophene (PTh) and polyaniline (PANI) with electrons-supplier property are being particularly used in supercapacitors applications. Electrons-supply flow of conducting polymers could be mitigated by the hybridization of the polymer with a high surface-area material that has additional necessary properties to improve the overall capacitive performance of the final composite. The conducting polymers-electrode porous structure and material surface area are determinant for the optimum capacitance, the fact is due to the surface phenomena-associated with supercapacitors $[8,21,28]$.

In the work at hand, we have prepareda composite material (P3HT-NiO) consisting of a blend of two donors, one is a polymer(P3HT), and the other is an oxide $(\mathrm{NiO})$ obtained through chronoamperometry method. The $\mathrm{NiO}$ is then added to the P3HT in various proportions (1$10 \%$ ) so that the P3HT-NiO deposit on indium tin oxide films by spin coating method. The capacity and photo electrochemical properties of the different composite material films were respectively studied by galvanostatic charge/discharge technics and photocurrent measurement.

\section{Experimental}

\section{Synthesis of NiO powder}

The Figure 1 represents the prepared electrochemically of $\mathrm{NiO}$ powder by applying a constant cathode potential of $0.91 \mathrm{~V}$ vs SCE on Fluorine-doped tin oxide (FTO) coated glass used as working electrode. Then, a graphite rod and SCE counter electrode used as a reference electrode. The electrolyte consisted in an aqueous solution of $0.1 \mathrm{M} \mathrm{NiSO} 4.6 \mathrm{H}_{2} \mathrm{O}, 0.1 \mathrm{M}$ $\mathrm{Na}_{2} \mathrm{SO}_{4}, 0.1 \mathrm{M} \mathrm{CH} \mathrm{CH}_{3} \mathrm{COONa}$ dissolved in deionizer water. The deposit of $\mathrm{NiO}$ was cleaned 
with deionised water and scraped with a blade. The issued powder was annealed for 1 hour at $500^{\circ} \mathrm{C}$.

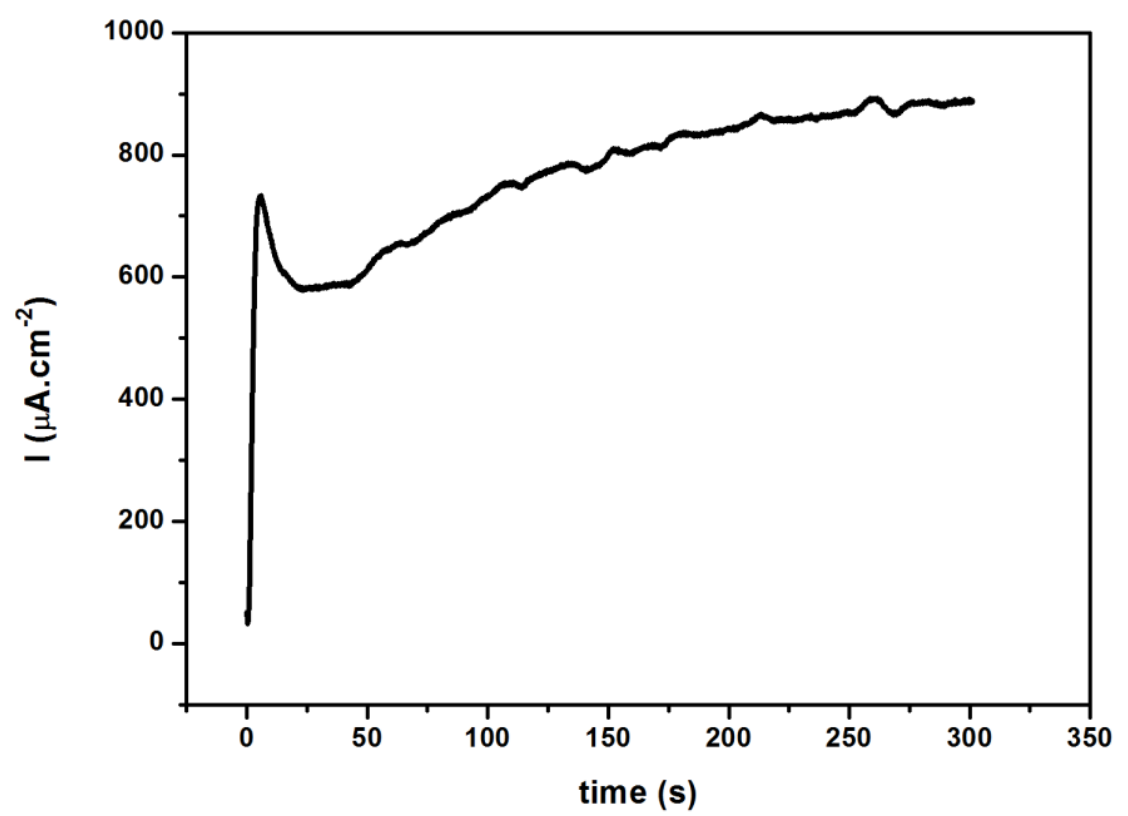

Figure1.Chronoamperograms of synthesis $\mathrm{NiO}$ at applying catholic potential of $0.91 \mathrm{~V}$ vs.SCE

\section{Preparation of (P3HT-NiO) thin films}

The ITO coated glass substrates used in this study were commercially obtained from the SOLEMS. The ITO's thickness is $100 \mathrm{~nm}$, its resistivity is about $25 \Omega / \mathrm{sq}$ and its averaged transmittance in the visible is $93 \%$. The substrates of ITO were cleaned through ultrasound wave device in, successively, deionised water, ethanol and acetone for $15 \mathrm{~min}$.

P3HT containing different amounts of $\mathrm{NiO}(0-10 \%$ wt.) prepared previously was dissolved in solution of Chlorobenzene $\left(\mathrm{C}_{6} \mathrm{H}_{5} \mathrm{Cl}\right)$, stirred during $24 \mathrm{~h}$ and deposited on ITO by spin-coating method at 500rpm for 30s. The spin coated films were annealed at $80{ }^{\circ} \mathrm{C}$ in air during $10 \mathrm{~min}$ (figure 2). 


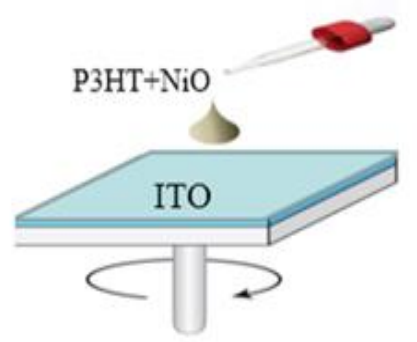

Figure2. Spin-coating process of ITO/P3HT and ITO/P3HT-NiO thin films.

\section{Characterizations}

The following electrochemical tests were carried out at normal environment temperature inside a single compartment cell using, as usual, the PGZ-301 Voltalab connected to a computer with operating software (voltamaster 4). The latter enables the electrochemical technique selection and establishes the aimed parameters. The measurements at electrochemical scale were operated in a three-electrode cell where indium tin oxide glass substrate (ITO) acted as working electrode, the saturated calomel electrode (SCE) as a reference electrode and the graphite rod as an auxiliary electrode.

The ITO/P3HT and ITO/P3HT-NiO (1, 5 and 10wt \%) film-layers were examined through diverse technical methods. For their parts, the X-ray analysis examination was carried out the Rigaku make powder X-ray diffract meter (model RINT 2100) with a CuKa waves $(\lambda=1.54 \AA)$. The necessary characterization of the films at hand was then conducted under a UV-visible a Shimadzu UV-1800 UV-VIS spectrophotometer following which the spectra were analyzed and stored in an appropriate file. Later on, the atomic force microscopy (AFM) images got through the MFP 3D atomic force microscope (from Asylum research), was in contact way. 
Furthermore, the issued images were used to quantify the film-layers roughness. The micrographs got from the Scanning electron microscopy were, as expected, from the Neo Scope, JEOL, JCM-5000.

The photo-electrochemical test of prepared films composites was carried out in $\left(\mathrm{LiClO}_{4} 0.1 \mathrm{M}+\mathrm{CH}_{3} \mathrm{CN}\right)$ electrolyte; the photocurrent was obtained after switching the light on and off, with an applied potential of -1.2 to $+1 \mathrm{~V}$ vs SCE. The working electrode was irradiated with white light and the illumination intensity of the lamp was $500 \mathrm{~W}$, the intensity of the illumination measured using a Luxmeter testo-540 was $100 \mathrm{Wm}^{-2}$.

\section{Results and discussion}

The nickel oxide film diffraction graphic (figure 3) witnessed peaks at $2 \theta=37^{\circ}, 43^{\circ}$, $62^{\circ}$. The resulted peaks values are likely to be those characterising the cubic $\mathrm{NiO}$ that are in harmony with specific standard values i.e. (JCPDS01-073-1519) [17,27]. The NiO grains size assessment is figured out through XRD according to Debye-Scherrer's law:

$$
\mathrm{D}=0.9 \lambda / \mathrm{w} \cos \theta
$$

Where $\mathrm{D}$ is the grains size, $\lambda$ is the $\mathrm{XRD}$ wavelength, $\mathrm{w}$ is the full width half maxima and $\theta$ is the peak position. Debye-Scherrer's law enables the NiO grains size that is estimated nearly around $25 \mathrm{~nm}$. 


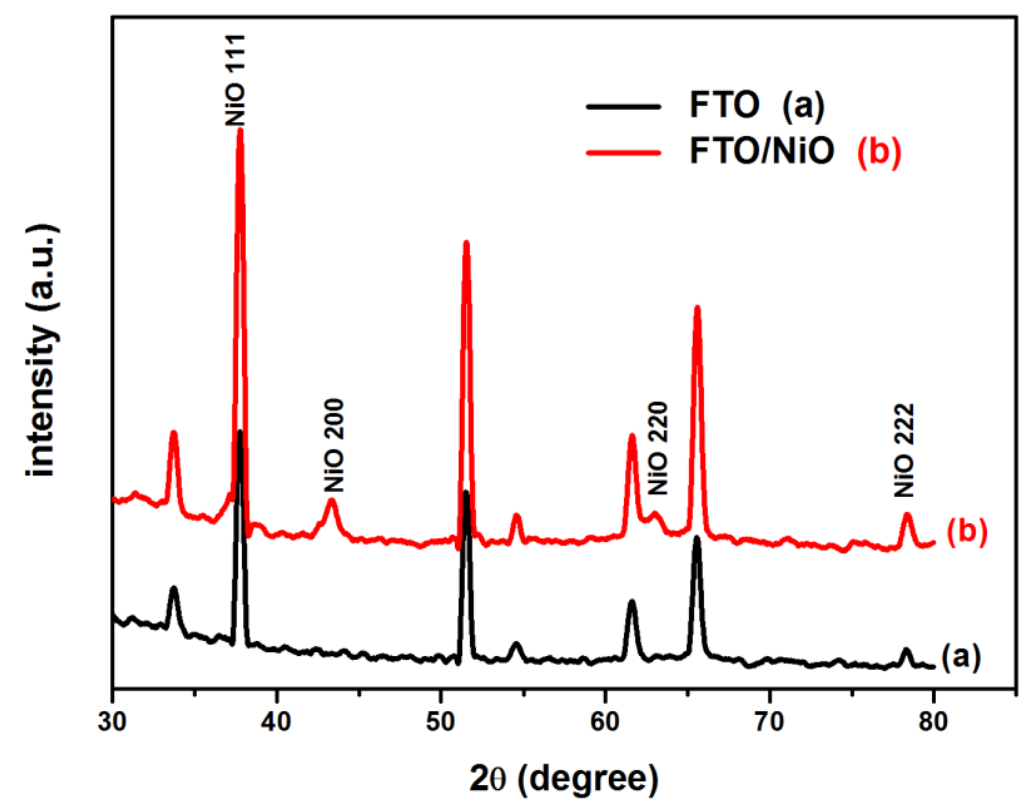

Figure3. XRD spectra of FTO (a) and $\mathrm{NiO}(\mathrm{b})$.

The figure 4 illustrates the XRD spectra of P3HT and P3HT-NiO (1-10\%) composite films, where the peaks are showed at $2 \boldsymbol{\theta}=37^{\circ}, 43^{\circ}, 62^{\circ}$ compared to the film which does not contain NiO. These results confirm the incorporation of $\mathrm{NiO}$ nanocomposite in $\mathrm{P} 3 \mathrm{HT}$ film. 


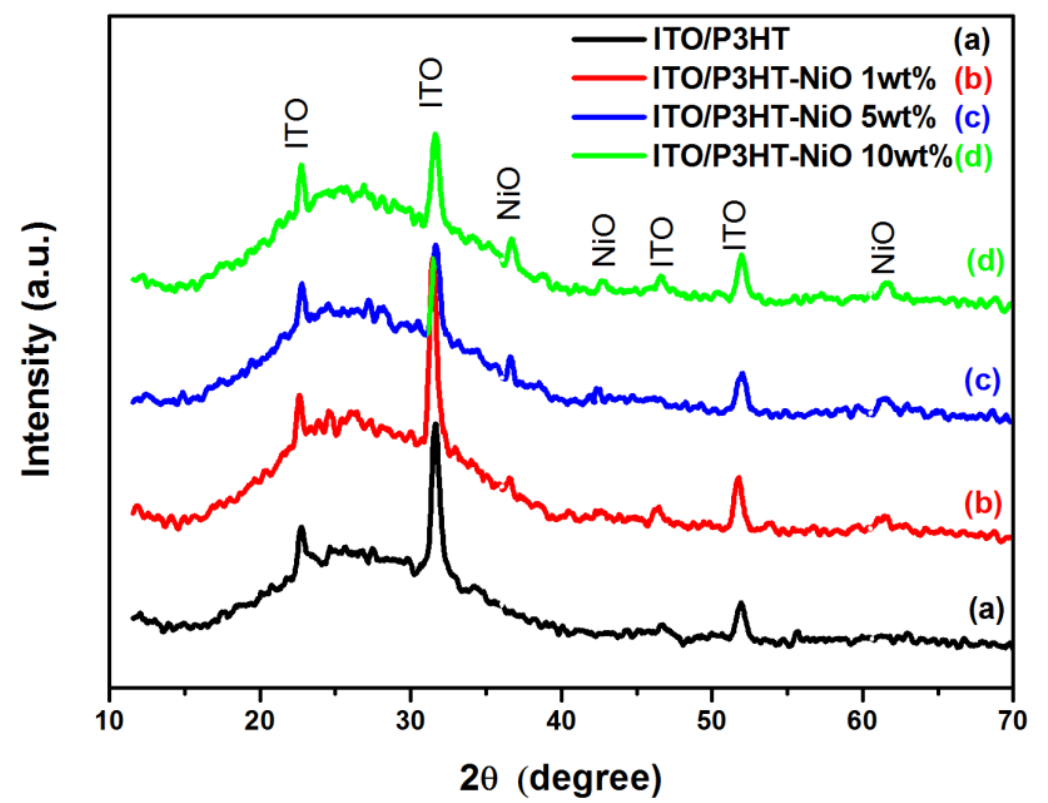

Figure4. XRD spectra of ITO/P3HT(a), ITO/P3HT-NiO 1wt\% (b), $5 \mathrm{wt} \%(\mathrm{c})$ and $10 \mathrm{wt} \%(\mathrm{~d})$.

The surface morphology of $\mathrm{P} 3 \mathrm{HT}$ and $\mathrm{P} 3 \mathrm{HT}-\mathrm{NiO}$ films has been investigated through scanning electron microscopy (SEM) analysis. The SEM images of each composite material film on the ITO are shown in Figure 5. The film of P3HT in figure (5A) presents smaller condensed crystalline domains, with a nodular-like structure [29]. The film of composite material P3HT-NiO consists of larger crystalline domains compared to P3HT. A surrounding film near the NiO clearly manifests; that is due to the attached P3HT polymeric chains [30]. 


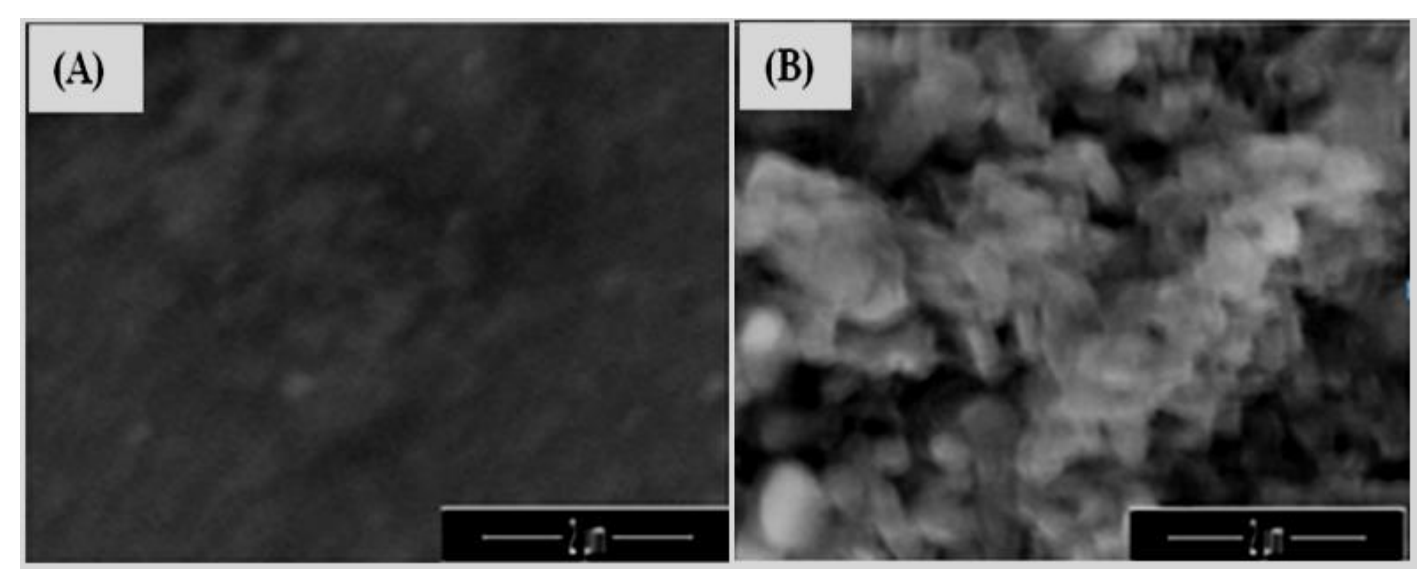

Figure5. SEM images of ITO/P3HT(A), ITO/ P3HT-NiO (B).

Atomic force microscopy (AFM) was used to investigate the surface morphology of the deposited filmsP3HT and $\mathrm{P} 3 \mathrm{HT} / \mathrm{NiO}$, as shown in Figure 6. The rates of surface roughness for P3HT blend (0, 1, 5 and $10 \mathrm{wt} \%)$ are respectively $4.42 \mathrm{~nm}, 9.32 \mathrm{~nm}, 10.13 \mathrm{~nm}$, and $18.27 \mathrm{~nm}$. It was noticed that the surface roughness enhances with the addition of $\mathrm{NiO}$ incorporated in P3HT up to $10 \mathrm{wt} \%$ and no considerable change manifests over the mentioned addition $\mathrm{NiO}$ proportion [31]. It is recognized that the surface morphology and the device interfaces are of capital role in order to achieve high performance of the P3HT. 

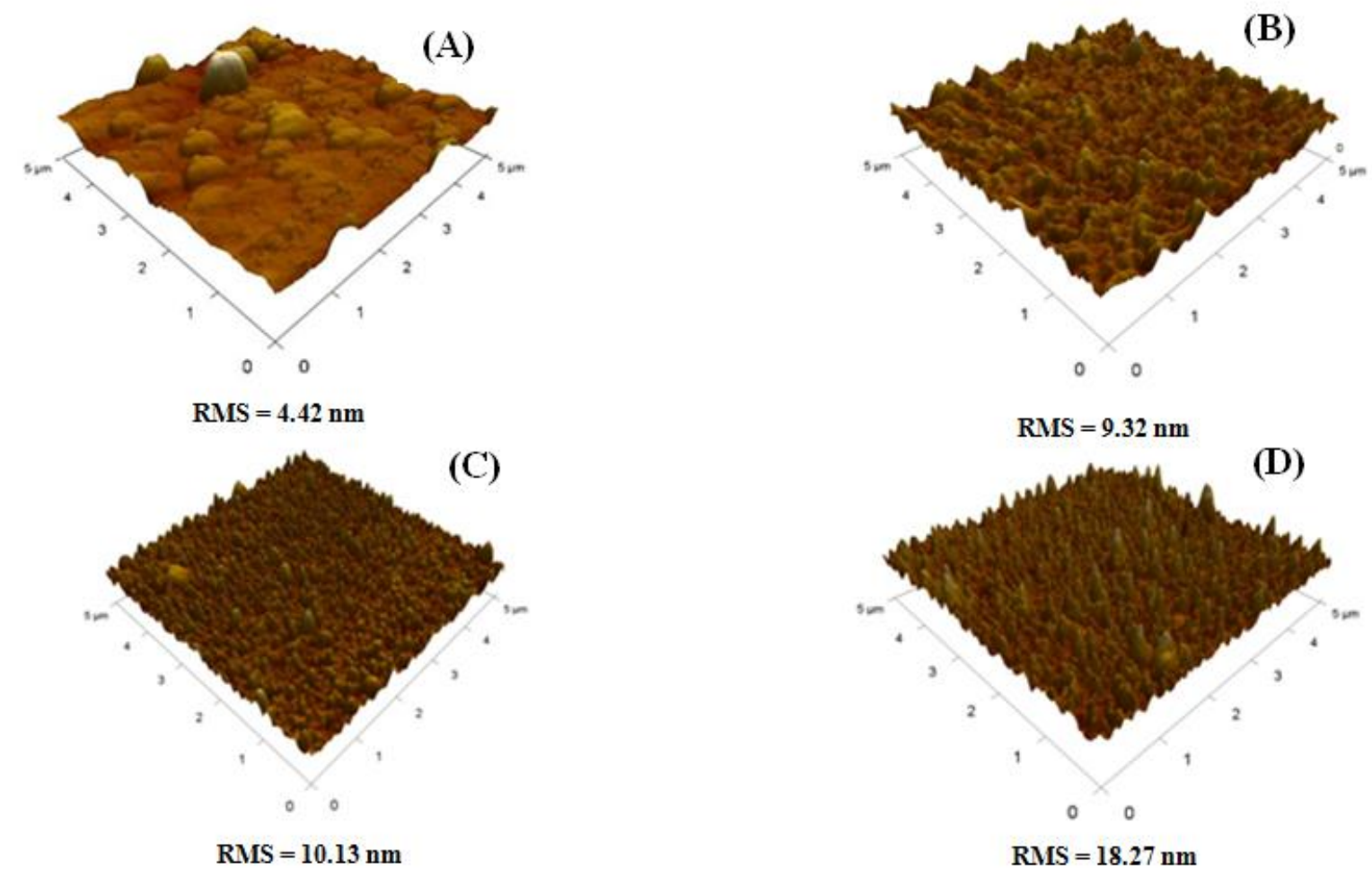

Figure 6. Atomic force microscopy images of ITO/P3HT(A), ITO/P3HT-NiO 1wt\% (B), $5 \mathrm{wt} \%(\mathrm{C})$ and $10 \mathrm{wt} \%(\mathrm{D})$.

The optical absorption studies have been experimented to investigate the influence of incorporation of different amount of $\mathrm{NiO}$ in $\mathrm{P} 3 \mathrm{HT}$ as illustrated in Figure 7. The results show an enhancement in the absorption of $\mathrm{P} 3 \mathrm{HT}$ after the incorporation of $\mathrm{NiO}$ of $(1-10 \mathrm{wt} \%)$. The absorption spectrum UV-visible is composed of a high energy area and a low energy zone corresponding respectively to amorphous and crystalline state P3HT chains. The absorbance spectrum of pure P3HT film consists of peaks at 690, 550 and $525 \mathrm{~nm}$, which are in accordance with that founded in literature [32-34]. The NiO insertion leads to clearly raising and overall intensity enhancement accordingly to the increase amount of $\mathrm{NiO}$ in the film. The boost in absorbance can be attributed to a soar in the active surface layer by introduction of $\mathrm{NiO}$ nanoparticles. 


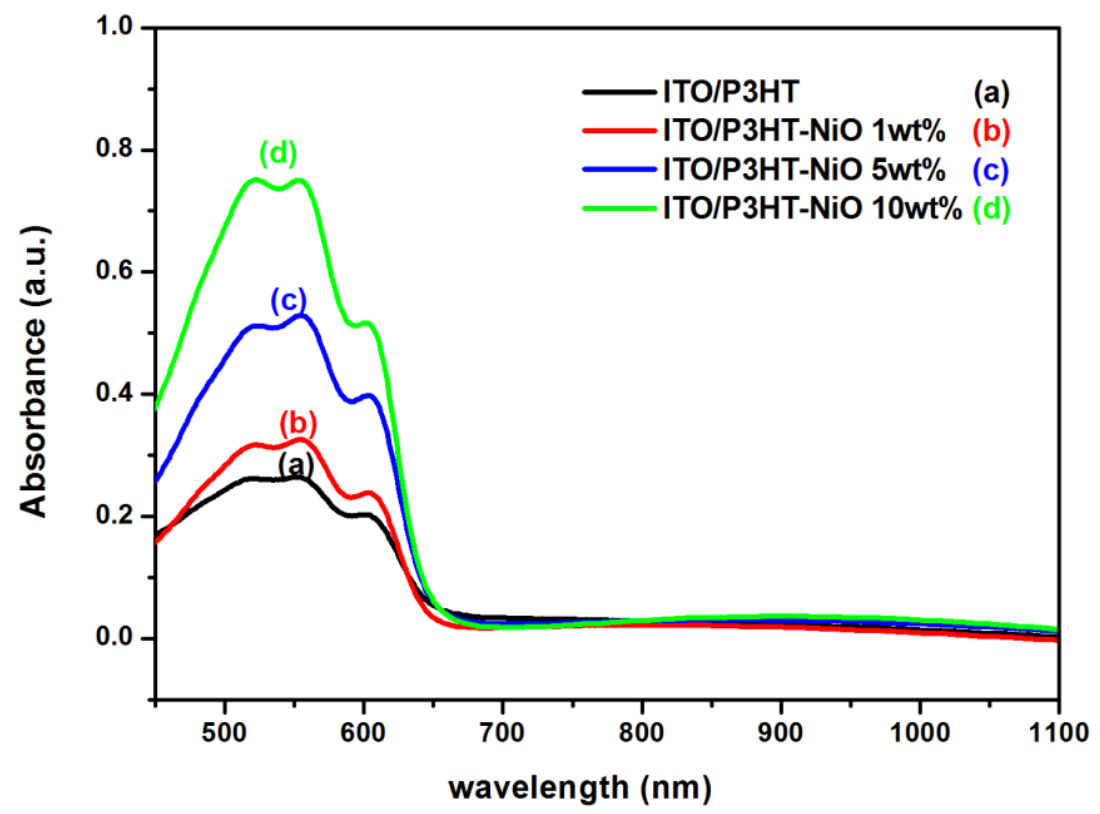

Figure 7. UV-visible spectra of ITO/P3HT(a), ITO/P3HT-NiO 1wt\% (b), $5 w t \%(c)$ and $10 w t \%(d)$.

The cyclic voltammetry is being the adequate method to characterize the materials capacitive performance of super capacitors. figure 8depicts the cyclic voltammograms of ITO/P3HT and ITO/P3HT-NiO (1, 5 and $10 \mathrm{wt} \%)$ composite films led in a potential scale of 0.3 to $0.8 \mathrm{~V}$ vs.SCE at various scan rates $\left(10,25,50,100 \mathrm{mVs}^{-1}\right)$. The noticed chief is that the CV curves of the electrode materials set are nearly rectangular-shaped.

First, in compared to the ITO/P3HT film, the whole ITO/P3HT-NiO composite films witnesses an obvious increase in the areas charge-discharge curves cyclic voltammetry plots, increasing thus the $\mathrm{NiO}$ mass incorporated in polymer matrix. Second, the cyclic plots points up to a reversible Red/Ox response as expected on the basis of the theoretical principles related to the scientific issue background. 

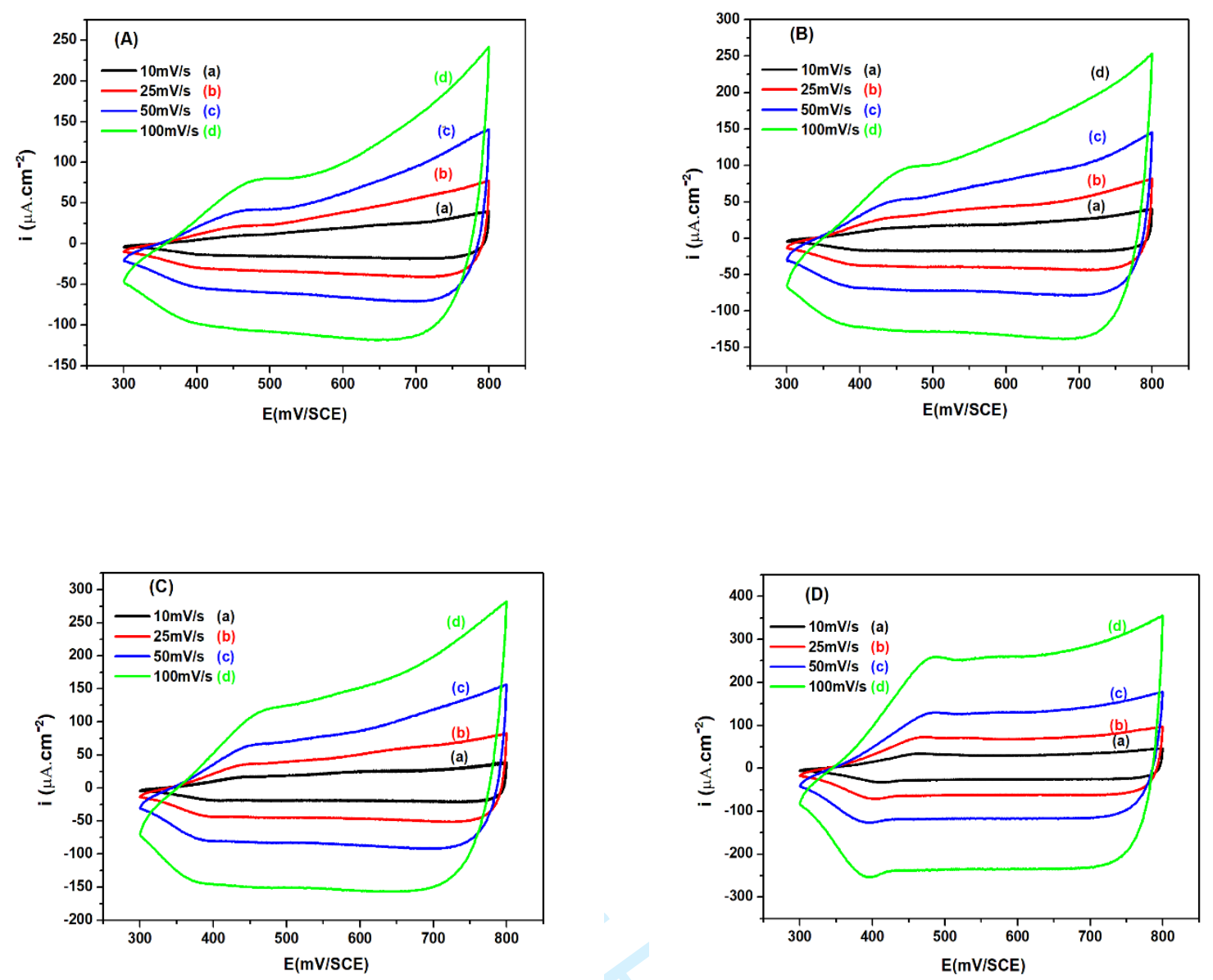

Figure 8. Cyclic voltammograms of ITO/P3HT (A), ITO/P3HT-NiO 1wt\% (B),

$5 \mathrm{wt} \%(\mathrm{C})$ and $10 \mathrm{wt} \%(\mathrm{D})$, at different scan rates in $0.1 \mathrm{M} \mathrm{LiClO}_{4} / \mathrm{CH}_{3} \mathrm{CN}$ electrolyte.

The high cyclic voltammetry response currents thus got for the ITO/P3HT-NiO $10 \mathrm{wt} \%$ composite film shows meaningfully a higher specific capacitance than ITO/P3HT, the observed fact is originated thanks to the rough structure of the ITO/P3HT-NiO composite films itself instead of the ITO/P3HT film. The ITO/P3HT-NiO composite films electrodes engage the high electrical conductivity parameter; as prerequisite, the $\mathrm{P} 3 \mathrm{HT}$ with large electrochemical active area is much preferred in order to maximize its draw interest from its 
efficiency. The NiO present inside enables a high contact interface between the P3HT and the electrolyte. Thus, the specific capacitance is accurately evaluated from the following equation (2):

$$
S C=\frac{\int_{E_{1}}^{E_{2}} i(E) d E}{2\left(E_{2}-E_{1}\right) m v}
$$

SC : Specific capacitance

$\mathrm{E}_{2}-\mathrm{E}_{1}$ : Potential window in cyclic voltammetry

$\int_{E_{1}}^{E_{2}} i(E) d E$ : Voltammetric charge obtained by integration of curve in CV.

$\mathrm{m}$ : weight of deposited materiel on working electrode, we used a balance with accuracy of 0.01 $\mathrm{mg}$

v: Scan rate.

Accordingly, the specific capacitances of ITO/P3HT and ITO/P3HT-NiO (1, 5 and 10wt \%) composite films in led at different scan rates are depicted in Figure 9. The ITO/P3HT film manifests a specific capacity next to $14 \mathrm{Fg}^{-1}$ at $10 \mathrm{mV} / \mathrm{s}$, but with the insertion of the $\mathrm{NiO}$ nanoparticles, a significant increase in specific capacitance occurred that were previously $16 \mathrm{Fg}^{-1}, 19 \mathrm{Fg}^{-1}$ and $25 \mathrm{Fg}^{-1}$ composite films respectively. It is worth mentioned that the raised enhancement bound in the electrochemical response may be in direct consequence with morphology occurred change following the $\mathrm{NiO}$ nanoparticles insertion. Otherwise, any increase in the composite material electro active area could normally occur. To summarize the experimental fact, any change in the morphology is wholly responsible for any ulterior change in the electrochemical behavior as proved by the SEM and AFM analysis. 


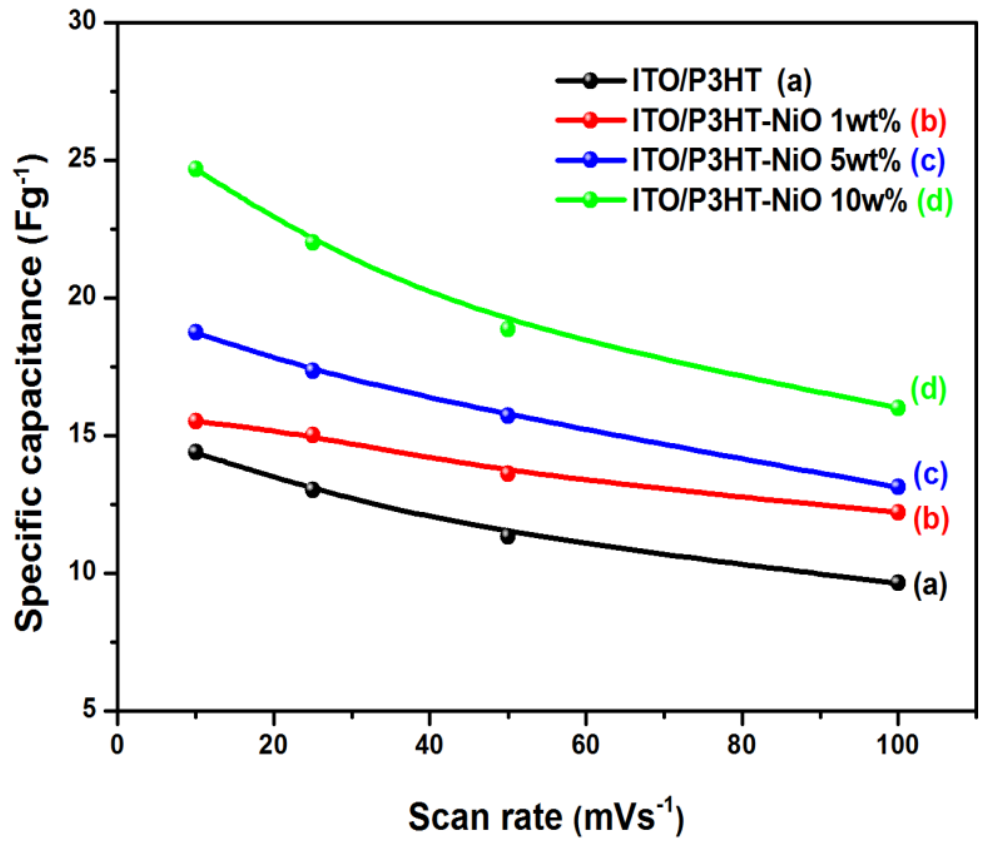

Figure 9. Specific capacitances of ITO/P3HT (a), ITO/P3HT-NiO 1wt\% (b), $5 \mathrm{wt} \%(\mathrm{c})$ and $10 \mathrm{wt} \%(\mathrm{~d})$ obtained at different scan rates.

The electrode materials have under gone a galvanostatic charge-discharge (GCD) tests. The figure 10 embodies the GCD curves of ITO/P3HT and the ITO/P3HT-NiO $(1,5$ and $10 \mathrm{wt} \%$ ) films at various current densities under voltages between 0.3 and $0.8 \mathrm{~V}$ vs. SCE. A typical charge-discharge curves almost equilateral triangle shaped, suggests a linear response to time potential in charge-discharge process that witnesses a well reversibility in the proceeded operation as the excellent capacitive behavior indicates. The full electrode materials resulted in two stages distinctive voltage drop stages with quick discharge in the primary potential zone but, in reverse, some delay in the second potential zone. The mentioned facts are proven to be significant in term of electrochemical performances. 
The figure 11 represents the GCD plots of the whole electrode materials set at current densities of $0.1,0.2,0.5,1$ and $2 \mathrm{~A} / \mathrm{g}$. It has been found as well that the increase in the current density the decrease in the discharge times of the electrode materials set occurs.

The ITO/P3HT-NiO 10wt $\%$ composite films reached the highest discharge time value of the materials tested, witnessing so a better specific capacitance. The specific capacitance (SC) of every electrode material was similarly calculated according the charge-discharge profile from to the equation (3):

$$
S C=\frac{i t}{m \Delta V}
$$

Where $\mathrm{i} / \mathrm{m}$ is the current density used, ' $\Delta \mathrm{V}$ ' the potential window, and ' $\mathrm{t}$ ' the discharge time in seconds. The ITO/P3HT-NiO 10wt $\%$ composite film reached the upmost specific capacitance of about $81.4 \mathrm{~F} / \mathrm{g}$ at a $0.1 \mathrm{~A} / \mathrm{g}$ current density. Besides, the ITO/P3HT, ITO/P3HT-NiO 1wt\% and ITO/P3HT-NiO 5wt\% gained 20.8, 26.2, and $38 \mathrm{~F} / \mathrm{g}$ capacitance values under the same current density applied $(0.1 \mathrm{~A} / \mathrm{g})$ as shown in Figure 11. Accordingly, the increase in current density causes a decrease in the whole all electrode materials set. The issued incidence is obviously explained by the subsequent fact following which barely fewer electrolyte ions are able to be in close contact with the inner space of the electrodes of energy storage at such high current densities. Likewise, the specific capacitance values at different current densities for the whole electrode materials have been assessed from the mathematical relation equation (2). 

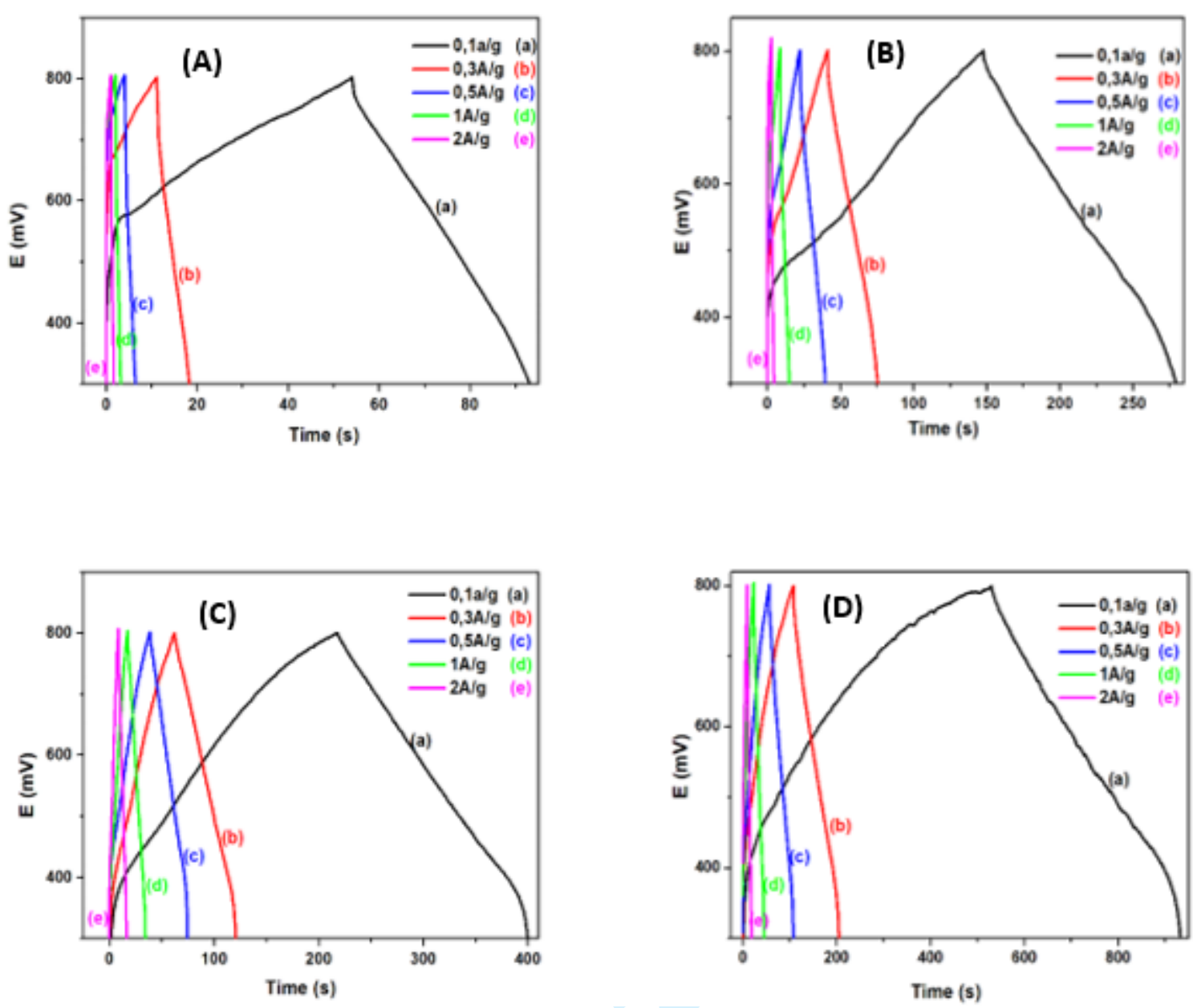

Figure 10. Galvanostatic charge-discharge curves of ITO/P3HT (A), ITO/P3HT-NiO1wt\% (B), $5 \mathrm{wt} \%$ (C) and 10wt\% (D), at different current density, in $0.1 \mathrm{M} \mathrm{LiClO}_{4} / \mathrm{CH}_{3} \mathrm{CN}$ electrolyte, carried out from 0.3 to $0.8 \mathrm{~V}$ vs SCE. 


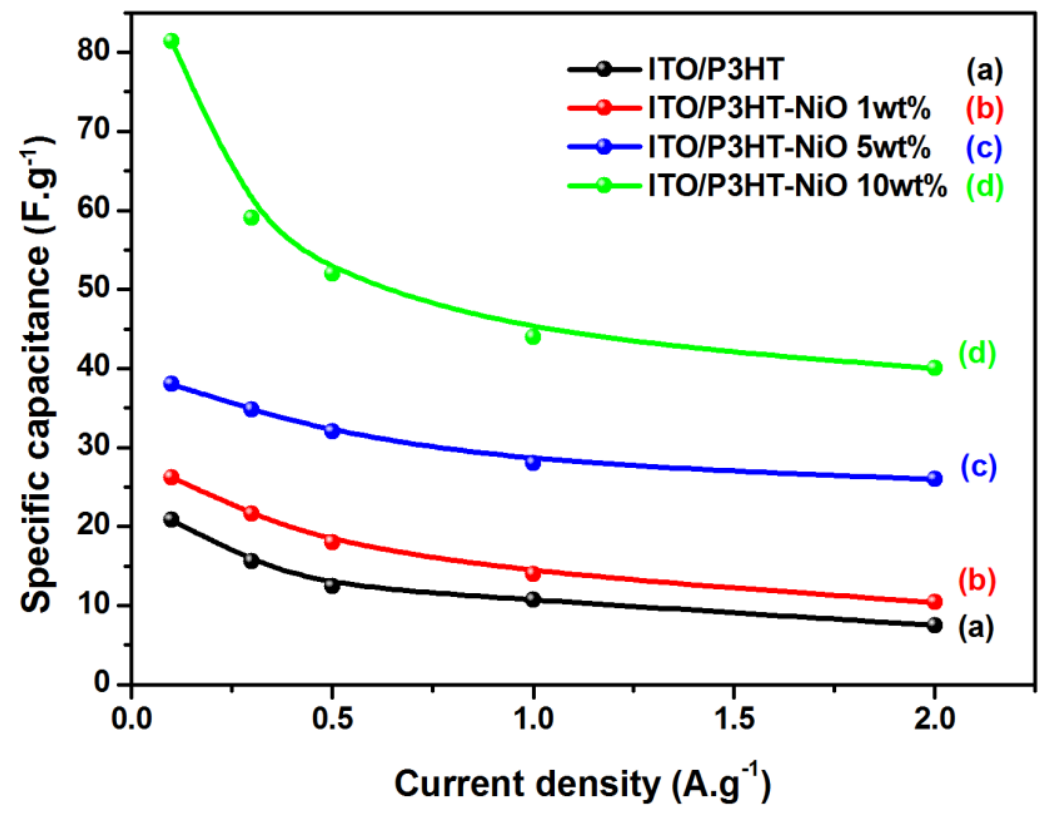

Figure 11.Specific capacitance of ITO/P3HT (a), ITO/P3HT-NiO 1wt\% (b), $5 \mathrm{wt} \%(\mathrm{c})$ and $10 \mathrm{wt} \%(\mathrm{~d})$, at different current density.

The spectra impedance of ITO/P3HT and ITO/P3HT-NiO composite films computed at open circuit potential $(0.1 \mathrm{~V}$ vs.SCE) is displayed as Nyquist diagrams in Figure 12.The films were submitted to analysis in $\left(\mathrm{LiClO}_{4} \quad 0.1 \mathrm{M}+\mathrm{CH}_{3} \mathrm{CN}\right)$ solution. The related measurements then plotted under frequency band between $100 \mathrm{KHz}$ and $50 \mathrm{mHz}$ and alternative current voltage of $10 \mathrm{mV}$.

As the issued outputs experimental facts show, the semicircle diameter decreases with the increase of the $\mathrm{NiO}$ content in $\mathrm{P} 3 \mathrm{HT}$ matrix. This propose a increase in the electric conductivity and a consequent important decrease in the resistance of the composite films that contain NiO, from $4906 \Omega . \mathrm{cm}^{2}$ for ITO/P3HT to $784 \Omega . \mathrm{cm}^{2}$ for ITO/P3HT-NiO $1 \mathrm{wt} \%, 128$ $\Omega . \mathrm{cm}^{2}$ for ITO/P3HT-NiO $5 \mathrm{wt} \%$ and $70.85 \Omega . \mathrm{cm}^{2}$ for ITO/P3HT-NiO $10 \mathrm{wt} \%$, these values are acceptable (Table 1).

Table 1: Impedance electrical parameter values corresponding to ITO/P3HT, ITO/P3HT-NiO 1,5 and $10 \mathrm{wt} \%$. 


\begin{tabular}{rllll}
\hline Element & \multicolumn{1}{|l}{ ITO/P3HT } & \multicolumn{1}{c}{$\begin{array}{c}\text { ITO/P3HT-NiO } \\
1 w t \%\end{array}$} & $\begin{array}{c}\text { ITO/P3HT-NiO } \\
5 w t \%\end{array}$ & $\begin{array}{c}\text { ITO/P3HT-NiO } \\
10 w t \%\end{array}$ \\
\hline$R_{1}\left(\Omega . \mathrm{cm}^{2}\right)$ & 65.16 & 50.24 & 61.08 & 63.77 \\
$\mathrm{R}_{2}\left(\Omega . \mathrm{cm}^{2}\right)$ & 4906 & 784 & 128 & 70.85 \\
$\mathrm{Q}_{2}\left(\mu \mathrm{F} . \mathrm{cm}^{2}\right)$ & 68.98 & $38 * 10^{-5}$ & $19.1 * 10^{-1}$ & $35.6 * 10^{-1}$ \\
& & & & \\
\hline
\end{tabular}

The outputted results point to a slower electron transfer in P3HT film. Nonetheless, the insertion of $\mathrm{NiO}$ grains in $\mathrm{P} 3 \mathrm{HT}$ film causes a significant improvement in the interaction of the conductive polymer chains.

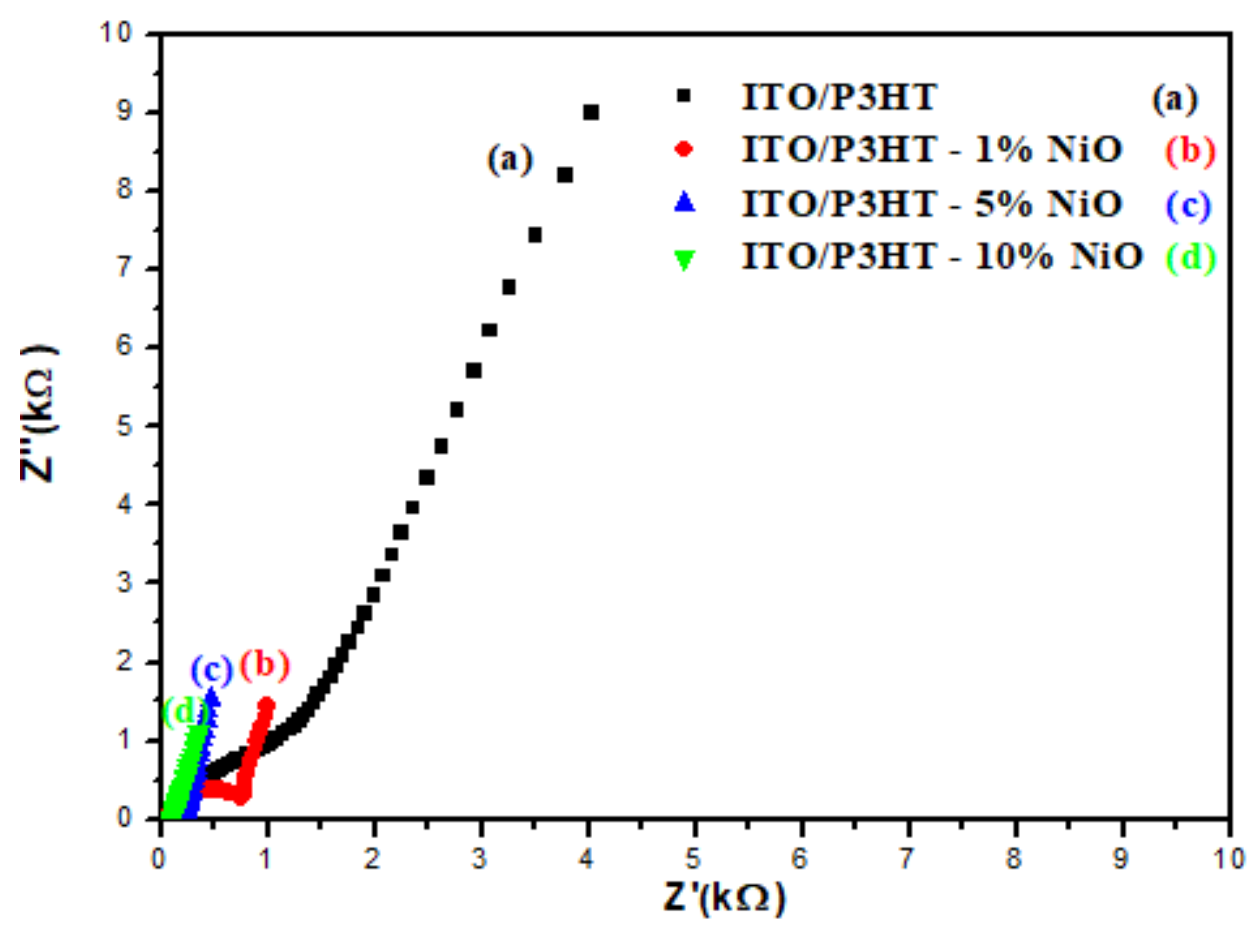




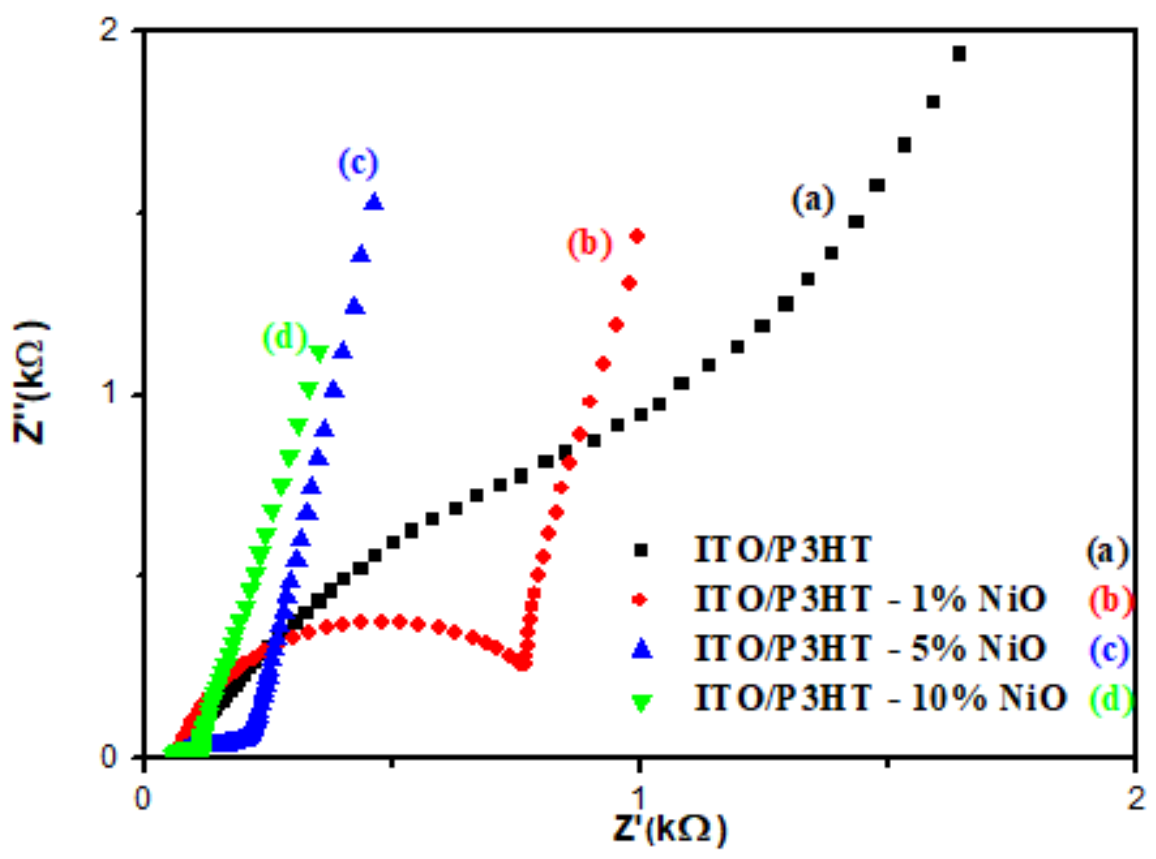

Figure 12. Nyquist plots of ITO/P3HT, ITO/P3HT-NiO 1wt $\%$, ITO/P3HT-NiO $5 \mathrm{wt} \%$ and ITO/P3HT-NiO $10 \mathrm{wt} \%$, in $0.1 \mathrm{M} \mathrm{LiClO}_{4} / \mathrm{CH}_{3} \mathrm{CN}$ electrolyte.

The figure 13 shows the photocurrent response of the ITO/P3HT and ITO/P3HT-NiO composite films under enlightenment. The issued output at cathodic applied potentials that corresponds to the photocurrent amplitude versus the applied potential related the prepared films. The investigation set tests carried out in $\left(\mathrm{LiClO}_{4} 0.1 \mathrm{M}+\mathrm{CH}_{3} \mathrm{CN}\right)$ electrolyte solution under an applied different potential between -1.2 to $1 \mathrm{~V}$ vs. SCE for a light intensity of 100 $\mathrm{mW} / \mathrm{cm}^{2}$. It is worth-mention that for the whole samples, both the photocurrent and the depletion region values increase as the applied cathodic potential increases. The fact at hand is fully expected seen that their p-type nature of semiconductor [35-39] and the amplitude of the photocurrent mostly increase with the increase of the $\mathrm{NiO}$ amount added in the polymeric film. 

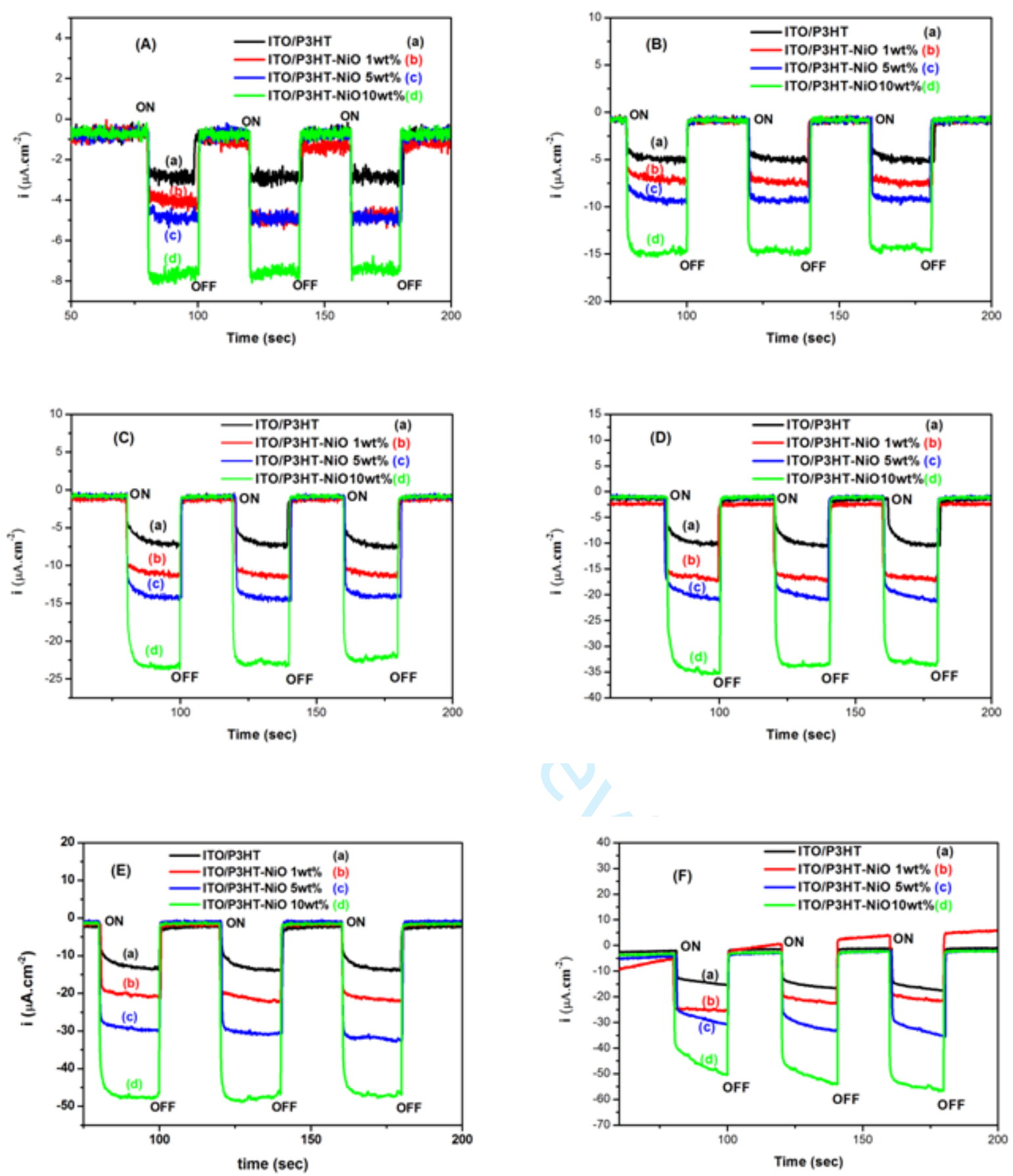

Figure 13. Photocurrent response ofITO/P3HT (a), ITO/P3HT-NiO $1 \mathrm{wt} \%$ (b), $5 \mathrm{wt} \%$ (c) and 10wt\% (d), at: -0.2 (A),-0.4 (B),-0.6 (C),-0.8 (D),-1 (E) and -1.2 (F) V vs.SCE in 0.1M $\mathrm{LiClO}_{4} / \mathrm{CH}_{3} \mathrm{CN}$ electrolyte, observed upon switching the white light on and off, at light intensity of $100 \mathrm{~mW} \mathrm{~cm}^{-2}$. 
The figure 14 shows photocurrent density as a function of applied potential range between -1.2 to $1 \mathrm{~V}$ vs SCE for ITO/P3HT and ITO/P3HT-NiO electrodes with different NiO amount. The photocurrent of polymer (P3HT) and composite films (P3HT-NiO) were negative at all potential range and this of composite films were higher than that for the nonmodified polymer.

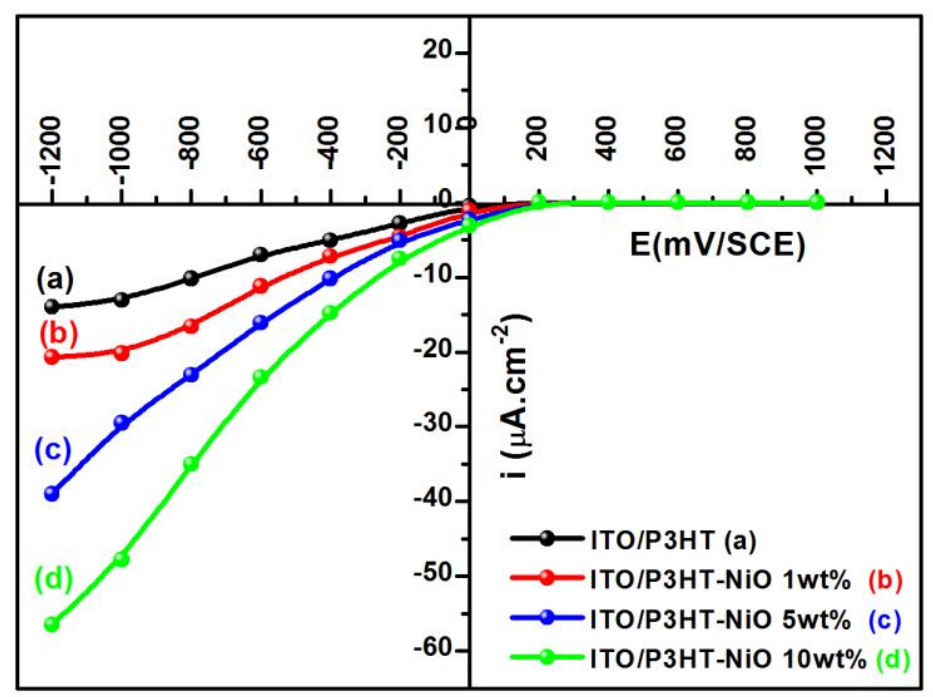

Figure14.Photocurrent-potential curve of ITO/P3HT (a), ITO/P3HT-NiO 1wt\% (b), ITO/ P3HT-NiO5wt\% (c) and ITO/P3HT-NiO 10wt\% (d), in a range of potential $-1,2$ to $1 \mathrm{~V}$ vs.SCE in $0.1 \mathrm{M} \mathrm{LiClO}_{4} / \mathrm{CH}_{3} \mathrm{CN}$ electrolyte.

\section{Conclusion}

The composite films of P3HT-NiO were obtained by dissolving P3HT with various $\mathrm{NiO}$ amount and were deposited by spin coating on ITO substrates. It's shown that the addition of $\mathrm{NiO}$ nanoparticles modified the morphology, spectroscopy and electrochemical properties of the $\mathrm{P} 3 \mathrm{HT}$ film. 
Moreover, the obtained specific capacity for the composite films (P3HT-NiO) was higher than that of pure polymer, which is due to the beneficial effect of $\mathrm{NiO}$ electronic conductivity.

Our results also demonstrate that $\mathrm{NiO}$ nanoparticles improved the optical and photoelectrochemical properties of P3HT composite films. The interface between a conjugated polymer and semiconductor should provide an efficient charge separation for the photo generated excitants, which improve the photocurrent of composites.

\section{References:}

[1] Machui F, Hösel M, Li N, Spyropoulos GD, Ameri T, Søndergaard RR, Jørgensen M, Scheel A, Gaiser D, Kreul K, Lenssen D, Legros M, Lemaitre N, Vilkman M, Välimäki M, Nordman S, Brabec CJ, Krebs FC (2014) P3HT: Non-Fullerene Acceptor based large area, semi-transparent PV modules with power conversion efficiencies of 5\%, processed by industrially scalable methods . Energy Environ Sci 7 :2792-2802. https:// doi:10.1039/C4EE01222D.

[2] Park S, Kim H, Kang Y, Kim D, Kang J (2010) Organic solar cells employing magnetron sputtered p-type nickel oxide thin film as the anode buffer layer. Solar Energy Materials \& Solar Cells 94:2332-2336. 10.1016/j.solmat.2010.08.004

[3] Krebs F, Alstrup J, Spanggaard H, Larsen K, Kold E (2004) Production of large-area polymer solar cells by industrial silk screen printing, lifetime considerations and lamination with polyethyleneterephthalate. Solar Energy Materials \& Solar Cells 83:293-300. https://doi:10.1016/j.solmat.2004.02.031.

[4] Ruzmetov D, Oleshko V, Haney P, Lezec H, Karki K, Baloch K, Agrawal A, Davydov A, Krylyuk S, Liu Y, Huang J, Tanase M, Cumings J, Talin A (2012) Electrolyte Stability 
Determines Scaling Limits for Solid-State 3DLi Ion Batteries. Nano let 12:505-511. https:// doi:10.1021/n1204047z .

[5] Hall P, Mirzaeian M, Fletcher S, Sillars F, Rennie A, Shitta-Bey G, Wilson G, Cruden A, Carter R (2010) Energy storage in electrochemical capacitors: designing functionalmaterials to improve performance. Energy Environ Sci 3:1238-1251. https://doi:10.1039/c0ee00004c. [6] Simon P, Gogotsi Y (2008) Materials for electrochemical capacitors. Nature Mater 7: 845854. https://845-854. doi:10.1038/nmat2297.

[7] Notten PHL, Roozeboom F, R. Niessen RAH, Baggetto L (2007) 3-D Integrated AllSolid-State Rechargeable Batteries. Adv Mater 19:4564-4567. https://doi:10.1002/adma.200702398.

[8] Sayah A, Habelhames F, Bahloul A, Nessark B, Bonnassieux Y, Tendelier D, ElJouad M (2018) Electrochemical synthesis of polyaniline-exfoliated graphene composite films and their capacitance properties. J Electroanal Chem 818:26-34. https://doi.org/10.1016/j.jelechem .201 8.04.016

[9] Irwin MD, Buchholz DB, Hains AW, Chang RPH, Marks TJ (2008) p-Type semiconducting nickel oxide as an efficiency-enhancing anode interfacial layer in polymer bulk-heterojunction solar cells. PNAS 105:2783-2787. https://doi: 10.1073_pnas.0711990105.

[10] Chapel A, Dkhil SB, Therias S, Gardette JL, Hannani D, Poize G, Gaceur M, Shah SM, Chung PWW, Ackermann CV, Margeat O, Rivaton A, Ackermann J (2016) Effect of ZnO nanoparticles on the photochemical and electronic stability of P3HT used in polymer solar $\begin{array}{llllll}\text { cells. Solar Energy } & \text { Materials } \& \quad \text { Solar Cells. }\end{array}$ https://doi:10.1016/j.solmat.2016.04.052. 
[11] Gonçalves R, Moraes FC, Pereira EC (2016) Reduced graphene oxide enhancing the photoelectrochemical properties of poly(3-hexylthiophene). Carbon 109:57-64. https://doi:10.1016/j.carbon.2016.07.041.

[12] Wang G, Hirasa T, Moses D, Heeger AJ (2004) Fabrication of regioregular poly(3hexylthiophene) field-effect transistors by dip-coating. Synth Met 146:127-132. https://doi:10.1016/j.synthmet.2004.06.026.

[13] Villers BT, Tassone CJ, Tolbert SH, Schwartz BJ (2009) Improving the reproducibility of P3HT:PCBM Solar Cells by Controlling the PCBM/ Cathode Interface. J Phys Chem C. 113:18978-18982. https://doi : 10.1021/jp9082163.

[14] Chan IM, Hong FC (2004) Improved performance of the single-layer and double-layer organic light emitting diodes by nickel oxide coated indium tin oxide anode. J Thin Solid Films 450:304-311. https://doi:10.1016/j.tsf.2003.10.022.

[15] Chtouki T, Soumahoro L, Kulyk B, Erguig H, Elidrissi B, Sahraoui B (2017) Spin-coated Tin-doped NiO thin films for third order non linear optical applications. Optik 136:237243. https://doi:10.1016/j.ijleo.2017.01.110.

[16] Nguyen DT, Ferrec A, Keraudy J, Bernède JC, Stephant N, Cattin L, Jouan PY (2014) Effect of the deposition conditions of $\mathrm{NiO}$ anode buffer layers inorganic solar cells, on the properties of these cells. Appl Surf Sci. 311:110-116. https://doi:10.1016/j.apsusc.2014.05.020.

[17] Wu MS, Huang YA, Yang CH, Jow JJ (2007) Electrodeposition of nanoporous nickel oxide film for electrochemical capacitors. Inter $J$ Hydro Ene 32:4153-4159. https://doi:10.1016/j.ijhydene.2007.06.001.

[18] Jamal RK, Naji I (2016) Electrical properties of pure $\mathrm{NiO}$ and $\mathrm{NiO}: \mathrm{Au}$ thin films prepared by using pulsed laser deposition. Iraqi Journal of Physics. 14:37-43. https://www.iasj.net/iasj?func=article \&aId=115237 
[19] Bandara J, Divarathne CM, Nanayakkara SD (2004) Fabrication of n-pjunction electrodes made of n-type $\mathrm{SnO}_{2}$ and p-type $\mathrm{NiO}$ for control of charge recombination in dye sensitized solar cells. J Solar Energy Materials \& Solar Cells. 81:429-437. https://doi:10.1016/j.solmat.2003.11.027.

[20] Srinivasan V, Weidner JW (1997) An Electrochemical Route for Making PorousNickel Oxide Electrochemical Capacitors. Electrochem Soc 144:210-213. doi: 10.1149/1.1837859.

[21] Gupta A, Akhtar AJ, Saha SK (2013) In-situ growth of P3HT/graphene composites for supercapacitor application. $\mathrm{J}$ Mater.Chem $\mathrm{xxx}$ :1-6. https://doi:10.1016/j.matchemphys.2013.04.015.

[22] Lou X, Zhao X, He X (2009) Boron doping effects in electrochromic properties of NiO films prepared by sol-gel. J Solar Energy 83:2103-2108. https://doi:10.1016/j.solener.2009.06.020.

[23] Xia XH, Tu JP, Zhang J, Wang XL, Zhang WK, Huang H (2008) Electrochromic properties of porous $\mathrm{NiO}$ thin films prepared by a chemical bath deposition. J. Solar Energy Materials \& Solar Cells. 92:628-633. https://doi:10.1016/j.solmat.2008.01.009.

[24] Patil PS, Kadam LD (2002) Preparation and characterization of spray pyrolyzed nickel oxide (NiO) thin films. App. Surf. Sci 199:211-221. https://doi.org/10.1016/S01694332(02)00839-5.

[25] Chrissanthopoulos A, Baskoutas S, Bouropoulos N, Dracopoulos V, Poulopoulos P, Yannopoulos SN (2011) Synthesis and characterization of $\mathrm{ZnO} / \mathrm{NiO} \mathrm{p}-\mathrm{n}$ heterojunctions: $\mathrm{ZnO}$ nanorods grown on $\mathrm{NiO}$ thin film by thermal evaporation. J. Photonics and Nanostructures $\quad-\quad$ Fundamentals and 9:132-139. https://doi:10.1016/j.photonics.2010.11.002. 
[26] Lu YM, Hwang WS, Yang JS, Chuang HC (2002) Properties of nickel oxide thin films deposited by RF reactive magnetron sputtering. Thin Solid Films. 420-421:54-61. https://doi : 10.1016/S0040-6090(02)00654-5.

[27] Sonavane AC, Inamdar AI, Shinde PS, Deshmukh HP, Patil RS, Patil PS (2010) Efficient electrochromic nickel oxide thin films by electrodeposition. J. Alloys. Compd.489:667-673. https://doi:10.1016/j.jallcom.2009.09.146

[28] Wu K, Zhao J, Wu R, Ruan B, Liu H, Wu M (2018) The impact of $\mathrm{Fe}^{3+}$ doping on the flexible polythiophene electrodes for supercapacitors. J. Electroanal Chem 823:527-530. https://doi.org/10.1016/j.jelechem.2018.06.052.

[29] Manoli K, Dumitru LM, Mulla MY, Magliulo M, Franco CD, Santacroce MV, Scamarcio G, Torsi L, A Comparative (2014) Study of the Gas Sensing Behavior in P3HTand PBTTT-Based OTFTs: The Influence of Film Morphology and Contact Electrode Position. Sensors 14:16869-16880. https://doi:10.3390/s140916869.

[30] Giannopoulos P, Andreopoulou AK, Lianos P, Nikolakopoulou A, Sygellou L, Kallitsis JK (2014) An alternative methodology for anchoring organic sensitizers onto $\mathrm{TiO} 2$ semiconductors for photoelectrochemical applications. J. Mater. Chem 2:20748-20759. https://doi: 10.1039/c4ta04515g.

[31] Wu F, Shan Y, Wang R, Zhu L (2016) Incorporation of dike to pyrrolopyrrole dye to improve photovoltaic performance of P3HT: PCBM based bulk heterojunction polymer solar cells. Organic Electronics 31:171-176. https://doi:10.1016/j.orgel.2016.01.028.

[32] Bielecka U, Lutsyk P, Janus K, Sworakowski J, Bartkowiak W (2011) Effect of solution aging on morphology and electrical characteristics of regioregular P3HT FETs fabricated by spin coating and spray coating. Organic Electronics 12:1768-1776. https://doi:10.1016/j.orgel.2011.06.027. 
[33] Chang H, Wang P, Li H, Zhang J, Yan D (2013) Solvent vapor assisted spin-coating: A simple method to directly achieve high mobility from P3HT based thin film transistors. Synth. Met. 184:1- 4. https://doi:10.1016/j.synthmet.2013.09.031.

[34] Gollu SR, Sharma R, Srinivas G, Kundu S (2014) Gupta D, Effects of incorporation of copper sulfide nanocrystals on the performance of P3HT: PCBM based inverted solar cells. Organic Electronics 15:2518-2525. https://doi:10.1016/j.orgel.2014.06.035.

[35] Gonçalves R, Moraes FC, Pereira EC (2016) Reduced graphene oxide enhancing the photoelectrochemical properties of poly (3-hexylthiophene). Carbon 109:57-64. https:// doi :10.1016/j.carbon.2016.07.041.

[36] Kim TH, Jeon HJ, Lee JW, Nah YC (2015) Enhanced electrochromic properties of hybrid P3HT/WO3 composites with multiple colorations. Electrochem. Commun 57:65-69. https://doi :10.1016/j.elecom.2015.05.008.

[37] Habelhames F, Lamiri L, Zerguine W, Nessark B (2013) Improvement of photoelectrochemical and optical characteristics of MEH-PPV using titanium dioxide nanoparticles. Mater. Sci. Semicond. Process 16:727-731.

https://doi.org/10.1016/j.mssp.2012.12.015

[38] Hab Elhames F, Nessark B, Boumaza N, Bahloul A, Bouhafs D, Cheriet A (2009) Electrochemical and photoelectrochemical study of gallium arsenide-polybithiophene composite, Synth. Met 159:1349-1352. https://doi:10.1016/j.synthmet.2009.03.009

[39] Habelhames F, Zerguine W, Lamiri L, Nessark B, Derbal-Habak H (2013) Morphology and photoelectrochemical characterization of MEH-PPV/PCBM composite film doped with TiO2 nanoparticles, Acta Metall. Sin. (Engl. Lett.) 26:373-377. https://doi: 10.1007/S40195$012-0269-\mathrm{z}$ 